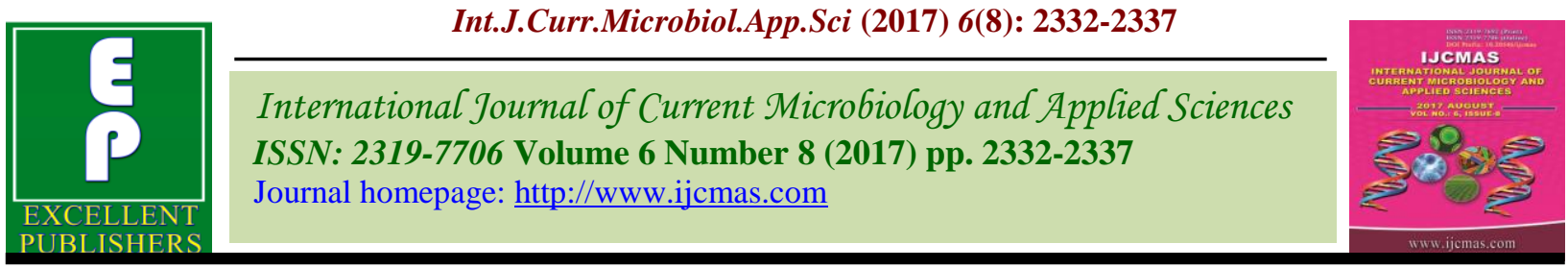

Original Research Article

https://doi.org/10.20546/ijcmas.2017.608.275

\title{
Comparative Effect of Integrated Crop Management and Farmers' Standard Practice in Chilli Crop
}

\author{
Salla Sowjanya*, R. Vijaya Kumari, V.V.R. Deekshitulu and J. Suresh \\ Department of Agricultural Economics, Prof. Jayashankar Telangana State Agricultural \\ University, Telangana, India \\ *Corresponding author
}

\begin{abstract}
A B S T R A C T
Keywords

ICM, Cost of

cultivation,

Returns, ROI,

Post-harvest cost,

Marketing cost.

Article Info

Accepted:

21 June 2017

Available Online:

10 August 2017

The present study was on Comparative effect of Integrated Crop Management and farmers' standard practice in Chilli growing areas in Telangana region, which was conducted in Gudepally village of Warangal district, where chilli formers adopting ICM technologies. For the study, 30 ICM and 30 Non- ICM farmers were randomly selected. Through the cost concepts and financial analysis the data was analysed. The average size of holding of ICM and Non ICM farmers was 4.4 and 2.54 ha respectively. For ICM and Non-ICM farmers, the total average cost of cultivation of chilli crop was ₹ 259188.98 and ₹ 243611.11 respectively. The gross returns per hectare of chilli cultivation for ICM and Non-ICM farmers were ₹ 463145.24 and $₹ 318600$ respectively in Gudepally village. Return on investment for ICM and Non-ICM farmers were 1.79 and 1.31 respectively. The post-harvest management cost of chilli cultivation per hectare was ' 9726.68 and 14800.33 under ICM and Non-ICM farms respectively. The overall analysis of the study revealed that adoption of ICM technologies in chilli cultivation results in high profits and export quality products. The state agricultural department should take initiatives, extension activities and trainings for promotion of the ICM technologies. Encourage mechanization in chilli cultivation.
\end{abstract}

\section{Introduction}

Agriculture continues to be a significant sector of Indian economy. Agriculture and allied sectors accounted for 14 per cent of the GDP in 2011-2012 and provides employment to over 60 per cent of the population (Economic survey, 2012-2013). Chilli is considered as one of the commercial spice crop, named as wonder spice.

It is the most widely used universal spice India is the largest producer, consumer and exporter of chilli, which contributes to about 40 percent of total world production, followed by China and Pakistan. It is estimated that
India produced 1378400 tonnes of chillies from an area of 787530 hectares in 2012-13 (Spice Board of India).

Integrated Crop Management (ICM) is a pragmatic approach to the production of crops, which combine a range of complementary methods to reduce a pest population below its economic injury level while minimising impacts on other components of the agro-ecosystem, thus taking into account the needs of producers, wider society and the environment (Kogan, 1998). This can include such things as IPM, 
soil, social and environmental management. Over recent decades the focus on crop production has moved from yields to quality and safety, then more recently sustainability. IPM is the integral part of ICM. Insect pests are well recognized as one of the major limiting factors in enhancing and sustaining agricultural production in India. India loses about $30 \%$ of its crops every year due to pests and diseases (Sharma and Rao, 2012).

Twenty per cent of the soil samples in the non-IPM fields had insecticide residues, while none of the soil samples in the IPM fields had residues (Kumari et al., 2012). In Okra fruit yield increased by 29.30 per cent over control along with highest benefit cost ratio (3.19) because of integrated nutrient management (INM) treatment (Bairwa et al., 2009). The fertilizer nutrient dose (NPK) that maximized yield of chilli was 119-97-92 kg/ha (Islam et al., 2008). In Chilli among the various organic manures, incorporation of vermicompost $(5 \mathrm{t} / \mathrm{ha})$ was considered as the best in improving plant height, number of fruits and fruit quality etc. application of neem cake was ranked next (Ankarao and Haripriya, 2003). Plant extracts and bio-agent formulations were quite safe to Coccinellids as evidenced by the natural activity of predators comparable to untreated control (Smitha, 2002). The intensity of pesticide use was higher on small farms compared to large farm (Gandhi and Patel, 1997). The multinational company ITC was included in the buying of the produce from ICM farmers for export purpose and it also gives technical assistance to the ICM farmers. The objective of the study is to compare the economics of ICM and Non ICM farmers in Gudepally village.

\section{Materials and Methods}

Gudepally village from Warangal district in Telangana was purposively selected wherein the Integrated Crop Management practices are largely adopted by chilli growing farmers, with the sample size of 60 (30 farmers adopting ICM and 30 farmers not adopting ICM) were randomly selected. Necessary data was collected through pre tested schedules and secondary data from Revenue Office / Mandal Revenue Office and Regional Agricultural Research Station, Warangal. Analysis of the collected data was done by working out simple averages and per centages.

The cost concepts were used to estimate the cost of cultivation. The cost concepts viz., cost $A_{1}$, cost $A_{2}$, cost $B$ and cost $C$ which are generally followed in farm management studies were adopted for the present study and examined as below.

Cost $\mathrm{A}_{1}$ : This cost includes value of hired human labour, owned and hired bullock labour, owned and hired machinery services, seeds, FYM, fertilizers, plant protection chemicals, depreciation, land revenue and interest on working capital. Cost $\mathrm{A}_{2}$ : Cost $\mathrm{A}_{1}$ + rent paid for leased in land. Cost B: Cost $\mathrm{A}_{1}$ / Cost $\mathrm{A}_{2}+$ rental value of owned land + interest on fixed capital excluding land value. Cost C: Cost B + imputed value of family labour. It gives total cost of cultivation.

Financial analysis includes Return on investment $=$ Gross returns $\div$ Total cost of cultivation. Net returns $=$ Gross returns Total costs. Total costs $=$ Total fixed costs + Total variable costs. Farm business income $=$ Gross income - Cost $A_{1}$. Family labour income $=$ Gross income - Cost B. Farm investment income $=$ Farm business income Imputed value of family labour.

\section{Results and Discussion}

The average size of holding of ICM and Non ICM farmers was 4.4 and 2.54 ha respectively. The cost concepts mostly used in the farm management studies are employed in 
the present study also. The cost concepts namely, Cost $A_{1}$, Cost $A_{2}$, Cost $B$ and Cost $C$ were used for the study. Out of these, Cost $\mathrm{C}$ is the most comprehensive cost as it includes both fixed and variable costs. The cost of cultivation of chilli of sample farmers according to cost concepts were worked out and presented in table 1 .

For ICM and Non-ICM farmers, the total average cost of cultivation (Cost C) of chilli crop was ₹ 259188.98 and ₹ 243611.11 respectively. Cost $A_{1}$ and Cost $A_{2}$ were same because the sample farmers are practicing chilli farming on their owned lands only. However, the Cost B was ₹ 240608.70 and ₹ 204577.41 respectively on ICM and NonICM farms..

A significant difference between ICM and Non-ICM was observed mainly because ICM farmers incurred more variable cost particularly on human labour and cost of plant protection chemicals than Non-ICM farmers. ICM farms require more human labour, because ICM farmers have higher awareness on minimum standards of cleanliness. ICM farmers in order to meet the quality standards, they used to spray non synthetic chemicals or harmless chemicals which are of high cost.

These results were in conformity with Varghese and Giraddi (2005). But, Non-ICM farmers were not concentrating on chemical usage because of their lower knowledge on harmful effects of chemical use. These observations are comparable with the results of Reddy et al., (2011) and similar results were also reported by Rao et al., (2007).

Returns per hectare of chilli cultivation were furnished in table 2 (Fig. 1). The gross returns per hectare realization from chilli cultivation by ICM and Non-ICM farmers were ₹ 463145.24 and $₹ 318600$ respectively. The returns for ICM farmers were significantly higher than the Non-ICM farmers. This was same with the net returns also. These observations are comparable with the results of Patil (1992).

The average yield of ICM and Non ICM farms was 65.67 and $49.83 \mathrm{q} /$ ha respectively. Return on investment was more for ICM and Non ICM farmers i.e., 1.79 and 1.31 respectively. It can be stated that one rupee investment made in the cultivation of chilli practicing ICM and Non ICM fetched ₹ 1.79 and ₹ 1.31 respectively. The ROI of NonICM farmers was significantly less than the ICM practices. These results were similar with the findings of Reddy et al., (2011) and Pawar (1995).

Similarly, the farm income measures like farm business income, family labour income and farm investment income were also high in ICM farms when compared with Non-IPM farms. Farm business income of ICM and Non-ICM farmers was ₹ 278627.35 and ₹ 167386.44 respectively. Similarly, family labour income was estimated at ₹ 222536.54 and ₹ 114022.59 for ICM and Non-ICM farmers respectively while, farm investment income was worked out to be ₹ 260047.08 and ₹ 128352.74 respectively. The returns from the ICM farms was significantly higher than the Non ICM farmers, because the ICM farmers realized more yields and received maximum price to their produce. The average yield and quality of chilli in the ICM farms was more compared to Non-ICM because the ICM farmers used optimum quantity of fertilizers, bio fertilizers, less pesticide sprayings and maintained minimum standards of cleanliness. Whereas in case of Non- ICM farmers, they are indiscriminately spraying pesticides this causes the pesticide residues in the produce. The returns are more because one of the multinational companies (ITC) was purchased produce with high price along with premium from ICM farmers which are residual free for export purpose. 
Fig.1 Returns from chilli cultivation

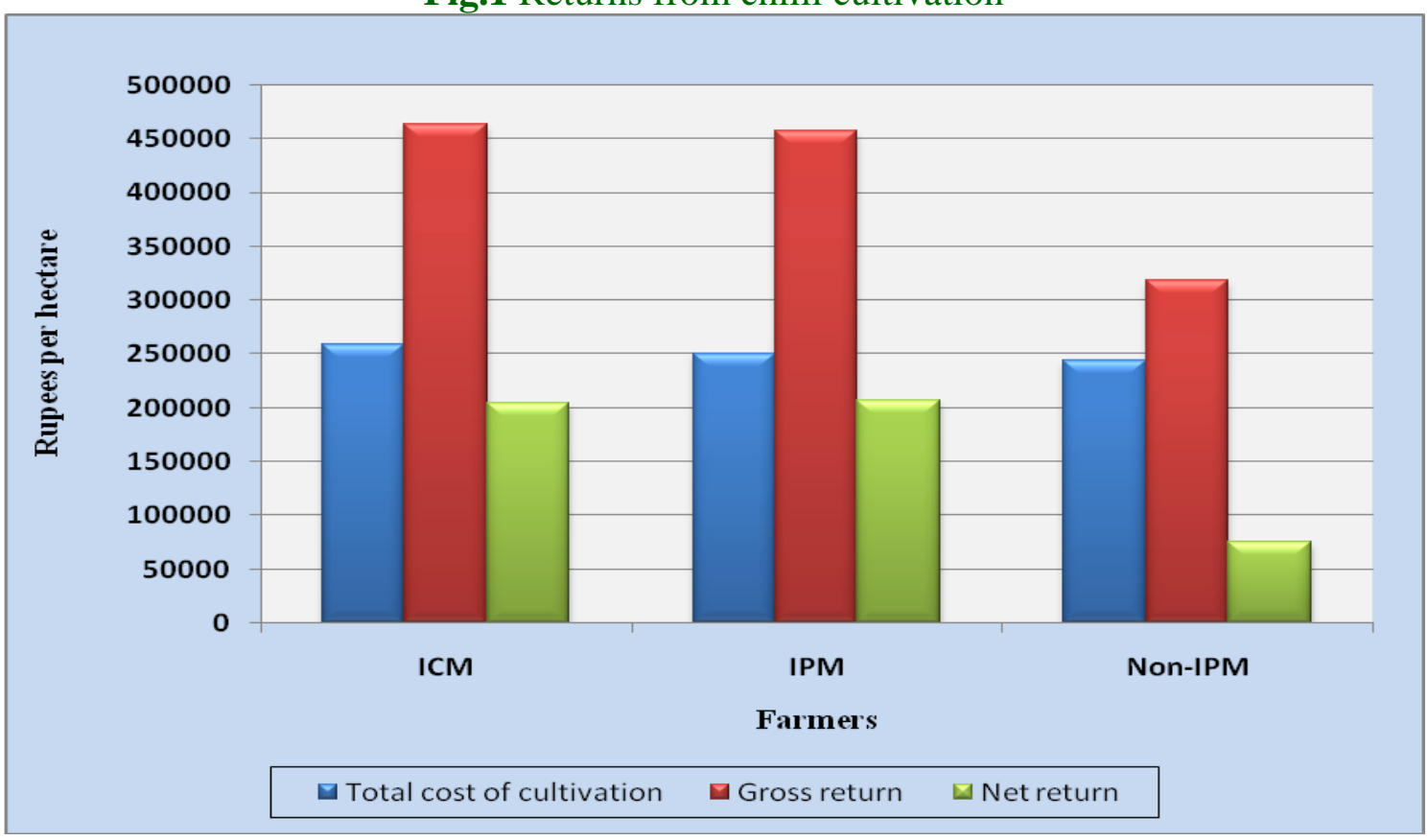

Table.1 Cost concepts of chilli in Gudepally village

\begin{tabular}{|l|l|c|c|}
\hline S. No. & \multicolumn{1}{|c|}{ Cost concept } & ICM (₹/ha) & Non ICM (₹/ha) \\
\hline 1. & Cost $A_{1}$ & 184517.88 & 151213.56 \\
\hline 2. & Cost $A_{2}$ & 184517.88 & 151213.56 \\
\hline 3. & Cost $\mathrm{B}$ & 240608.70 & 204577.41 \\
\hline 4. & Cost C & 259188.98 & 243611.11 \\
\hline
\end{tabular}

Table.2 Returns from chilli cultivation ( $₹ /$ ha)

\begin{tabular}{|c|l|c|c|}
\hline S. No. & Particulars & ICM & Non ICM \\
\hline 1 & Yield (q/ha) & 65.67 & 49.83 \\
\hline 2 & Gross return & 463145.24 & 318600.00 \\
\hline 3 & Total cost & 259188.98 & 243611.11 \\
\hline 4 & Net return & 203956.26 & 74988.89 \\
\hline 5 & Return on investment & 1.79 & 1.31 \\
\hline 6 & Farm business income & 278627.35 & 167386.44 \\
\hline 7 & Family labour income & 222536.54 & 114022.59 \\
\hline 8 & Farm investment income & 260047.08 & 128352.74 \\
\hline
\end{tabular}

Table.3 Post-harvest management cost of chilli in Gudepally village (₹/ ha)

\begin{tabular}{|c|l|c|c|}
\hline S. No & \multicolumn{1}{|c|}{ Particulars } & ICM & Non- ICM \\
\hline 1 & Drying & $4495(46.69)$ & $5107.15(34.47)$ \\
\hline 2 & Grading & $4506.68(46.81)$ & $2716.08(18.33)$ \\
\hline 3 & Packing & $725(6.49)$ & $610.14(4.22)$ \\
\hline 4 & Bag cost & 0 & $6366.96(42.98)$ \\
\hline & Total & $9726.68(100)$ & $14800.33(100)$ \\
\hline
\end{tabular}

Note: Figures in parenthesis are per centages to their respective total 
Table.4 Marketing cost of chilli (₹/ ha)

\begin{tabular}{|l|l|c|c|}
\hline S. No & Particulars & ICM & Non- IPM \\
\hline 1 & Packing cost & $3392.34(100)$ & $2557.95(11.10)$ \\
\hline 2 & Transportation cost & 0 & $9169.33(39.78)$ \\
\hline 3 & Market fee & 0 & $5401.93(23.44)$ \\
\hline 4 & Commission & 0 & $5401.93(23.44)$ \\
\hline 5 & Hamali charges & 0 & $518.27(2.25)$ \\
\hline & Total market charges & $3392.34(100)$ & $23049.41(100)$ \\
\hline
\end{tabular}

Note: Figures in parenthesis are per centages to their respective total

Table 3 indicates the various post-harvest management costs incurred by the chilli sample farmers

The post-harvest management cost of chilli cultivation per hectare was ' 9726.68 and 14800.33 under ICM and Non-ICM farms respectively. The various post-harvest activities include drying, grading, packing and bag cost.

The share of each of these costs in total postharvest management costs constitute 46.69, $46.81,6.49$ and zero per cent respectively in case of ICM farmers. The same were 34.47 , $18.33,4.22$ and 42.98 per cent in case of NonICM farmers respectively.

Bag cost was zero for ICM farmers because ITC was providing bags to these sample farmers on free of cost for selling their produce them. Therefore, the post-harvest management cost was more on Non-ICM farm.

The details of marketing cost of chilli were furnished in table 4. The various marketing costs included were packing cost, transportation cost, market fee, commission charges and hamali charges.

The share of each of these costs in total marketing cost was $11.10,39.78,23.44,23.44$ and 2.25 per cent respectively for Non-ICM sample farmers. Less incurrence of marketing costs by ICM / IPM farmers in the Gudepally village was because the entire produce was sold to ITC in the field itself. Most of the ICM $(93.33 \%)$ farmers opined that fertilizer usage was reduced with the adoption of ICM technologies through regular soil testing and using recommended doses of fertilizer.

Similarly, the number of pesticide sprayings were also reduced on these farms as opined by cent per cent of ICM farmers, it reduces the environmental pollution. Cent per cent of the ICM sample farmers felt that soil health improved due to ICM practices.

Cent per cent of the sample farmers adopted border and trap crops which are a part of ICM technologies. This had helped the sample farmers in prior identification of pests and diseases and undertaking the suitable plant protection measures immediately.

Likewise erection of bird perches in the ICM / IPM chilli farms, enabled the birds to sit on them and eat away the insects in the field as expressed by cent per cent of sample farmers.

In conclusion, the adoption of ICM technologies in chilli was found to be more profitable, environmentally safe and sustainable.

The overall analysis of the study revealed a positive impact of adoption of ICM technologies in chilli cultivation.

\section{Policy implications}

The state agricultural department should take initiatives for further promotion of ICM technologies through their wide spread extension activities. Encourages the mechanization to reduce the labour problem. 


\section{References}

Ankarao, A and Haripriya, K. 2003. Response of chilli to integrated use of manures and fertilizers. National seminar on new perspectives in Spices, Medicinal and Aromatic Plants. ICAR Complex, Goa.

Bairwa, H.L., Shukla, A.K., Mahawer, L.N., Kaushik, R.A., Shukla, K.B and Ameta, K.D. 2009. Response of integrated nutrient management on yield, quality and physico-chemical characteristics of okra cv. Arka Anamika. Indian Journal of Horticulture. 66(3): 310-314.

Gandhi, V.P and Patel, N.T. 1997. Pesticides and the environment: A comparative study of farmer's awareness and behaviour in Andhra Pradesh, Punjab and Gujarat. Indian Journal of Agricultural Economics. 52 (3): 519-529.

Islam, M.S., Howlader, M.I.A., Rafiquzzaman, S., Bashar, H.M.K and Al-Mamun, M.H. 2008. Yield Response of Chili and $\mathrm{T}$. Aman Rice to NPK Fertilizers in Ganges Tidal Floodplain. Journal of Soil and Nature. 2 (1): 07-13.

Kogan, M, 1998. Integrated Pest Management: historical perspectives and contemporary developments. Annual Review of Entomology, 43: 243-270.

Kumari, B.R., Rao, G.V.R., Sahrawat, K.L and Rajasekhar, P. 2012. Evaluation of Integrated Pest Management in Reducing Insecticide Residues in Plant, Soil and Water. Indian Journal of Plant Protection. 40 (4): 268-272.

Patil, B. V. 1992. Sensitivity of field collected Helicoverpa armigera. Pestology. 17: 1921.
Pawar, A.D. 1995. Integrated Pest Management demonstrations-cum-training in rice and cotton crops. Plant Protection Bulletin. 47 (1-4): 40-72.

Rao, C.A.R., Rao, M. S., Naraiah, P., Malathi, B and Reddy, Y.V.R. 2007. Profitability of cotton on a pest management continuum in Guntur district of Andhra Pradesh. Agricultural Economics Research Review. 20(2): 273-282.

Rao G.V. R and Rao V.R. 2010. Status of IPM in Indian Agriculture: A Need for Better Adoption. Indian Journal of Plant Protection. 38(2):115-121.

Reddy, C.M., Reddy, G.K., Tirupamma, K and Reddy, S.K.V. 2011. Economics of integrated pest management (IPM) in chilli in Guntur district of Andhra Pradesh. International Journal of Plant, Animal, Environmental Sciences. 1(1):140-143.

Sharma, D and D.V. Rao. 2012. "A Field Study of Pest of Cauliflower, Cabbage and Okra in some areas of Jaipur" International Journal of Life Sciences Biotechnology and Pharma Research., 1(2): 2250-3137.

Smitha, M.S. 2002. Management of yellow mite, Polyphagotarsonemus latus (Banks) (Acari; Tarsonemidae) on chilli. M.Sc., Thesis. University of Agricultural Sciences, Dharwad.

Varghese, T.S and Giraddi, R.S. 2005. Integration of neem cake in the plant protection schedule for thrips and mite management in chilli (cv. Byadagi). Karnataka Journal of Agricultural Sciences. 6: 154-156.

www.indianspices.com

\section{How to cite this article:}

Salla Sowjanya, R. Vijaya Kumari, V.V.R. Deekshitulu and Suresh, J. 2017. Comparative Effect of Integrated Crop Management and Farmers' Standard Practice in Chilli Crop. Int.J.Curr.Microbiol.App.Sci. 6(8): 2332-2337. doi: https://doi.org/10.20546/ijcmas.2017.608.275 